\title{
The Implementation of Case Study Method to Develop Student's Activities and Characters
}

\author{
Agung Nugroho ${ }^{1}$, Dhi Bramasta ${ }^{2}$, Pamujo $^{3}$ \\ Universitas Muhammadiyah Purwokerto \\ Corresponding e-mail : ' agungnugroho@ump.ac.id
}

\begin{abstract}
Learning activities are carried out to result in a development of knowledge, behavioral values, and skills of students as a deliberate practice. These activities will result in knowledge and skills leading to the improvement of students' learning results. This study was aimed at implementing cooperative learning model through case study method as an attempt to direct and develop students' learning activities as well as develop cooperative character to support learning and teaching activities. The subjects were fourth year students of UMP elementary school. The study covered 2 cycles consisting of 2 meetings for each cycles. Each meeting employed three steps consisting of Plan, Do, See. The result showed that case study method is considered effective to develop activities and cooperative characters of students. The lesson study activity was conducted as planned and able to influence the quality of learning process significantly.
\end{abstract}

Keyword: Case Study Method, Cooperative, Student's Activity

Abstrak. Aktivitas belajar merupakan suatu kegiatan yang dilakukan untuk menghasilkan perubahan pengetahuan, nilai sikap, dan keterampilan pada siswa sebagai latihan yang dilaksanakan secara sengaja. Aktivitas belajar siswa akan berdampak pada terbentuknya pengetahuan dan keterampilan yang mengarah pada peningkatan hasil belajar siswa. Tujuan kegiatan ini yaitu menerapkan pembelajaran kooperatif metode studi kasus sebagai upaya untuk mengarahkan dan meningkatkan akivitas belajar siswa serta menumbuhkan karakter kerjasama guna mendukung keterlaksanaan proses belajar dan mengajar. Kegiatan dilaksanakan di kelas IV SD UMP dalam betuk lesson study. Kegiatan terdiri dari 2 siklus dimana masing-masing siklus terdiri dari 2 pertemuan. Tiap pertemuan dilaksanakan dengan tahapan Plan, Do dan See. Hasil kegiatan diperoleh bahwa metode studi kasus dirasa cukup efektif untuk meningkatkan aktivitas dan karakter kerjasama siswa. Kegiatan Lesson Study yang diselenggarakan pada umumnya berjalan lancar dan mampu memberikan dampak yang cukup signifikan terhadap kualitas proses pembelajaran.

Keyword: Metode Studi Kasus, Kerjasama, Aktivitas Siswa

\section{INTRODUCTION}

Learning activities are carried out to make some progress of knowledge, behavioral values, and skills of students as a deliberate practice. They include all activities of interaction between students and teachers to achieve the learning objectives. To develop students' activities, teachers are required to: (1) ask questions and guide students in a discussion, (2) give tasks to solve problems, analyze, make decisions and so on, (3) conduct any experiments by collecting information, giving opinions and so on. In a learning process, students' activeness is required as 
it determined their success in learning. It shows that all individuals should be active in learning as it significantly influence the result of leaning.

Having a meeting and discussion with the school, it was decided that PDS would be conducted in class four with the teaching material of globalization. From the discussion and observation, students of that class tend to have high level of activeness. Therefore, the team focused to lead the classroom activities to improve cooperative character among students to solve students' noise. It is expected that the improvement of students cooperative behavior and activities influenced students' motivation and achievement in learning.

Based on the situation above, the researchers were interested in guiding students into positive activities involving cooperative elements and students' interaction. For that reason, case study learning method was then selected. Case study method is a learning design based on school. This method is in the form of explanation towards problems, and certain events of situations. It can also be used to develop critical thinking and find new solution of a solved topic. The collaborative discussion used in this model will lead students to interact with their peers by harnessing its steps. These steps was later continued by sharing and presentation of discussion result. It as expected that students activity and cooperation will develop.

\section{METHODS}

This study was carried out in the form of lesson study whose subjects were students of class four in UMP elementary school. This lesson study lasted for 4 weeks comprising 2 cycles. Each cycle covers plan, do, see. The aspect of character that should be developed is cooperative attitude and students' activity. The method used in this study is lesson study.

\section{RESULT AND DISCUSSION}

\section{A. RESULT}

\section{a. Reflection of Cycle 1}

The step of See or learning evaluation was carried out directly after the step of do. In the step of see, the team discussed about all activities in the step of do. Based on the observation, there were some issues that should be revised in the cycle 2 . They were as follows:

1) Lesson plans should be revised to focus on the case study method.

2) Time management applied by model teachers should be improved that all planned activities could be carried out well.

3) The teacher could not gain the learning objectives. In the first meeting, they did not make any conclusion of the learning activities.

4) Class conditioning should be paid attention as classroom grouping was still problematic.

5) The teacher should organize the students' discussion.

6) Teamwork could not be performed optimally during the classroom discussion. Only few students performed well during the discussion.

7) in selecting students to present the discussion result, the teacher should choose randomly.

Based on the discussion, it was suggested that there should be an improvement and planning of learning for the following meeting so that the lesson study can run well and gain the planned objectives.

\section{b. Reflection Result in Cycle 2}

Reflection step of cycle 2 was carried out at the end of the activity. In this step, 
the team discussed about all activities in the step do. From the all activities in cycle II consisting of 2 meeting, the input and improvement for the following cycle were as follows.

1) The teacher should have guided all students to be active during discussion as only few students were actively engaged.

2) The teacher should provide more innovative learning media to attract students' attention.

3) The teacher should guide student during discussion from beginning to the end.

\section{B. DISCUSSION}

The change of the recent paradigm demand the change of learning process in the classroom. Teachers' role recently are directed to be the facilitators that can help students in learning rather than solely present the materials. Teachers should be able to engage students in learning activities optimally. Learning will be more meaningful provided that students are given the opportunities to participate in any learning activities. Thus, students will be able to manifest their abilities inside or outside the classroom.

Activities are essential principles or basics in learning-teaching interaction. Learning activities is very crucial to students as they give opportunities for students to be in touch with the learning objects. By doing so, knowledge construction processwill be better. Sardiman in Nurmala (2014) stated that children have energy to develop and to shape themselves. It indicates that children hold the most important role in developing themselves while teachers provide guidance and plan the learning activities

The learning system of active students will be more effective if it is applied in learning process in schools. in other words, learning system emphasize students activities physically, intellectually and emotionally to gain the learning objectives which combine cognitive, affective and psychomotor aspects (Wianti, 2010:16). Learning is considered successful should there be an active involvement of students to learn. In addition, the success of teachers in teaching rely on students' activities in learning while students' success relies on teachers' role in teaching. Students' active involvement in learning will cause high interaction level between teachers and students and among students which may draw their full potentials. Students' learning activities will lead to an achievement of knowledge and skills referring to students learning improvement. Therefore, students who actively involve in learning will comprehend the materials better. Therefore, students' possibility to gain better learning objectives will be higher. There is a relationship between students' learning activities and learning results. It is required further study to determine whether their relationship is positive or negative.This study is expected to prove the positive relationship between students active involvement in teaching with their learning achievement. Based on the results of the implementation of Lesson Study, students and the general cooperation in learning activities has increased. Students who tend to be active in the classroom can boost student activity other group sutdi case when working in groups. This is in line with research results Wulandari (2015) in his article that showed that teamwork increases after applying Lesson Study in learning. In line with Wulandari, research Jaelani (2013) shows that not much different from the activities related to cooperation in the cooperative learning students through lesson study. 


\section{CONCLUSION}

Based on the study, it can be concluded that :

1. Learning model of case study is considered sufficiently effective to improve students' activities and cooperative character.

2. The lesson study was carried out successfully. However, some issues dealing with time allotment should be taken into account in the following study.

3. The implemented lesson study can influence the quality of learning process significantly.

4. The improvement for the learning material of globalization through this lesson study covers:

a. Cooperation which was improvement of students' performance in every meeting having implemented each cycle. It could be better presented in the second meeting of cycle 2 .

b. Activities that improve in every cycle. It indicates that students possessing active behavior can be guided in discussion activities.

\section{REFERENCES}

Anggraeni, Leni. 2012. Penerapan Metode Studi Kasus Dalam Upaya Meningkatkan Kemampuan Berpikir Kritis Mahasiswa Pada Mata Kuliah Hubungan Internasional. Jurnal Media Komunikasi FIS Vol. 11 .No 1 April 2012 : 1 - 15. Universitas Pendidikan Indonesia

Hasanah, Istikhomatul . 2016. Upaya Meningkatkan Sikap Peduli Sosial Dan Prestasi Belajar Pkn Materi Pengaruh Globalisasi Di Lingkungan Melalui Metode Studi Kasus Bikinan Siswa Pada Siswa Kelas IV SD Negeri 1
Karangbawang Kecamatan Ajibarang. Skripsi. PGSD UMP.

Nisaa, Milla Yuanti. 2015. Pengaruh Metode Pembelajaran Mind Map Terhadap Aktifitas Belajar IPS Siswa Kelas VII Semester 1 SMP Negeri 2 Batang Tahun Ajaran 2014/2015. Skripsi. UNNES.

Nurmala, Desy Ayu. Lulup Endah Tripalupi. Naswan Suharsono. 2014. Pengaruh Motivasi Belajar Dan Aktivitas Belajar Terhadap Hasil Belajar Akuntansi. Jurnal Jurusan Pendidikan Ekonomi. Undiksha.

Suyantiningsih dkk. 2011. Pengembangan Karakter Mahasiswa Melalui Model Pembelajaran Kolaboratif (Collaborative Learning) Pada Mata Kuliah Pameran Teknologi Pendidikan. Laporan Lesson Studi. UNY.

Wianti Anggit. 2015. Pengaruh Aktivitas Belajar Siswa Terhadap Hasil Belajar Geografi Pada Sekolah Menengah Atas di Kecamatan Gombong Kabupaten Kebumen. Skripsi. UNNES. 